\title{
To contract or to operate publicly? Observations from the bus service reform transition process in Malta.
}

\section{Keywords:}

Bus, Reform, Operations, Malta, Thematic Analysis, Attitudes

Classification codes:

L1 Market Structure, Firm Strategy, and Market Performance; L2 Firm Objectives, Organization, and Behaviour; L8 Industry Studies: Services; L9 Industry Studies: Transportation and Utilities.

\begin{abstract}
Efficient bus service operations involve a multitude of simultaneous activities, including ensuring delivery of a service quality that satisfies customers. This paper refers to the case of bus service operations in Malta. Prior to 2011 bus service operations in Malta had not changed fundamentally for four decades. Since 2011 , following a major bus service reform, bus service operations have changed a further two times. This paper discusses the four models of bus service operations experienced in Malta: Model 1 - a monopoly, Model 2 privatisation through competitive tendering, Model 3 - nationalisation, and Model 4 privatisation through negotiation. The paper aims to provide insights on the four models and applies a stakeholders' approach to identify how these models have affected attitudes towards the bus service in Malta amongst the public. Thirty-four in-depth, semi-structured interviews were conducted with Maltese residents and tourists visiting Malta. The main bus service characteristics that influenced the stakeholders' evaluations of the service were identified using thematic analysis. The analysis indicates that bus patrons are primarily interested in service delivery; they are not influenced by how the operator is selected. The paper draws conclusions on the wider relevance of these findings to bus operations at an international level.
\end{abstract}

\section{Introduction}

Bus operations are influenced by market structures, and by the institutions that regulate them. Similarly, procurement of bus operations and eventual contractual agreements affect bus operations (Mathisen \& Solvoll, 2008). These in turn can influence service levels and service quality, and customer satisfaction. Hence, it is important to understand how major changes to market structures and bus operations influence the publics' attitudes towards the bus. This paper aims to do just that, using Malta as a case study.

Over the last four years, Malta has experienced three major transformations in bus service operations. Prior to that, the bus service operated under the form of a private-based monopoly, which had lasted for 40 years. In 2011, a bus service reform, implemented with a "big bang", privatised and monopolised operations once more. The following year, the service was nationalised, and then a year later privatised again. Bus operations have always been planned at a national level in Malta.

We start by presenting an overview of existing literature on bus operations. In section 3, we explore the four different types of bus services that were implemented in Malta. Section 4 presents the research methodology, and section 5, presents our findings on the attitudes of Maltese residents and tourists visiting Malta towards the bus service. The bus service operations, together with the stakeholders' attitudes imply that there is a need for further improvement to obtain a modal shift, from the car to the bus. 
The paper provides insights on how the four different operational models tried in Malta influenced the service quality, and the stakeholders' attitudes towards the bus service. The conclusion provides suggestions for bus service operations that are likely to run in several other similar environments.

\section{Review of literature on bus operations and user experiences}

To the authors' knowledge, research linking the market structure for the setting up of bus operations and user experiences has to date not been explored in a bus reform context. The literature review first explores the role of bus users as important stakeholders. It then moves on to identify the impact of attitudes and expectations on bus use, and explores the market structure and its influence on bus service quality. The final section briefly explores the importance of regulation in relation to service quality.

\subsection{Bus users as stakeholders}

Stakeholders in bus-oriented environments refer to individuals or groups that influence or are influenced by three main features of the service-delivery chain: modelling, operation and end-user (Mahmoud et al., 2012). Of course, bus operators are important stakeholders for the delivery of a bus service. The consideration of bus users as stakeholders should be equally important; a considerable amount of literature available on the matter supports this statement (Eboli \& Mazzulla, 2007,2008; dell'Olio, Ibeas, \& Cecín, 2010; Cirillo, Eboli, \& Mazzulla, 2011; De Oña, De Oña, Eboli, \& Mazzulla, 2013).

Providing a public transport service that is appealing to all stakeholders is a difficult task (Sakai \& Takahashi, 2013). For instance, bus operators' requirements are different from bus users' requirements. An ideal scenario for bus operators includes providing the required minimum level of service at the lowest cost possible (Hensher \& Houghton, 2004). Bus users' requirements vary by several variables, such as age, gender, journey purpose and location, thus creating different segments (Lyons et al., 2008 and Scheiner \& Holz-Rau, 2007). Hence, bus service characteristics in different locations may influence their customers' evaluations differently. For example, in a study by dell'Olio, Ibeas, \& Cecin (2011) in Santander (Spain), bus users expected a punctual, clean, and comfortable bus service. In another study in Edinburgh (Scotland), bus users expected a calm and serene experience (Stradling, Carreno, Rye, \& Noble, 2007).

This paper focuses on two types of stakeholders - Maltese bus users, and tourists. We consider stakeholders' views essential because their satisfaction serves as an indicator to service quality (Wang et al. 2010). If customers are not satisfied with the service and the service quality delivered does not meet their needs then they are likely to switch to using alternative modes of transport. We also consider that customers base their evaluations of the bus service directly, from their experiences (Meek et al., 2009 and Hensher et al., 2010), and indirectly, from hearsay (Bajada, 2015).

\subsection{The impact of expectations and attitudes on bus use}

\subsubsection{Expectations}

Customers' expectations are what bus users feel that a bus service provider should offer, rather than would offer (Teas, 1993). Two conflicting paradigms on expectations exist 
(Robledo, 2001). The 'disconfirmation paradigm' - customers evaluate a service by comparing their perceptions of the service with their expectations (Oliver, 1980); this comparison leads to an overall customer satisfaction level (Andreassen 1995). If expectations of the promised service are high, and the service performance does not live up to these expectations, the stakeholders would have negative evaluations towards the service (Muñoz \& Gschwender, 2008). The 'perception paradigm' argues that expectations are misleading, and only the customers' perception is required (Hastorf, Schneider, \& Polefka, 1970).

In this paper we adopt a middle ground. Whilst expectations may help shed light on perceptions of and attitudes towards a bus service, expectations should be treated with caution. This is because of the subjective nature of expectations.

\subsubsection{Attitudes}

People's attitudes are influenced by service quality (dell'Olio et al. 2011). This does not necessarily mean that changing attitudes translates into behaviour change. A study in the Netherlands showed that when environmentally conscious car users were informed that they drove more than they perceived, they modified their views to continue using their personal transport (Tertoolen, van Kreveld, \& Verstraten, 1998). Research has shown, however, that focusing more on service quality characteristics, increases the chances of improving bus patronage (Eboli \& Mazzulla 2012).

Service quality characteristics can be categorised in eight key factors. These include: 'availability', 'accessibility', 'fare structure', 'information', 'time', 'customer experience', 'comfort', 'security' and 'impact on the environment' (European Committee for Standardisation 2002, Paulley et al. 2006 and dell'Olio et al. 2010).

\subsection{The bus market structure and its influence on bus operations}

\subsubsection{Market structure}

Market structure influences service delivery, which in turn influences the publics' attitudes (Hefetz \& Warner, 2012). The way the market is structured affects whether a bus service is a monopoly, or whether there is competition, and whether the bus service is operated publicly or privately, thus influencing also the financial aspect of operations.

Operations of bus services have changed throughout the decades (Gwilliam, 2008). Three typical market structures exist. These are 'no competition', 'competition in the market' and 'competition for the market'.

In 'no competition' the bus service is typically nationalised - government plans and operates the bus service as a public monopoly. Examples of similar operations take place in India (Chennai) (Badami \& Haider, 2007), and the United States. In the former case, bus service operations suffer from infrequency, and overcrowding (Mitric \& Chatterton, 2005). In the latter case, the federal government fund public transport, and public bus organisations provide the bus service (Roschlau, 2008). As observed by Blundred (1991), monopolies and direct operator subsidy create an ideal environment in which trade unions have a significant say. They can start dictating wages, favour inefficient operating practices and strongly resist change. 
In 'competition in the market' operating rights are granted to private companies, and onstreet competition between operators provides the opportunity for more innovation and specialisation within the private sector (Badami \& Haider, 2007 and Tang \& Lo, 2008). Cases where similar liberal regimes operate include Britain (outside London) and New Zealand (Finn, 2003).

'Competition for the market' allows open competition between different transport operators. This type of market structure is typically applied where local operators are not available, or where competition in the market is not economically feasible (Cambini \& Filippini, 2003). The regulating authority plans the service, and private companies compete for the operation of the bus service. The bus service in London is a typical example of this approach, where companies compete for the bus routes (White, 1999).

\subsection{Regulation}

There is a general agreement that privatised bus services are better regulated, and are associated with a lower operating cost (Blundred, 1991; Amaral, 2008). Preference towards a regulated approach derives from a separation in roles between the regulator and the operator.

No single organisation has control over all the factors involved in ensuring service quality (Balcombe et al., 2004). Nash and Bray (2014) suggest the introduction of independent regulators to encourage the provision of good service quality that suites community interest. Understanding cultural contexts is also necessary in determining the success of any change to the bus system (Preston, 2014). Another important component is trust (Walters \& Jansson, 2008). Trust, in this case, involves the operator and regulator abiding by agreed rights, risks and obligations that compose a professional working relationship based on good faith, continued transparency and consultation (Walters \& Jansson, 2008).

\section{Overview of bus operations in Malta}

In Malta there are 759 licensed road vehicles per 1,000 inhabitants (National Statistics Office, 2014). Based on the responses from a one day travel survey (the National Household Travel Survey) journeys in Malta are mainly done by car (75\%), followed by $15 \%$ by public transport - out of which $11 \%$ of the journeys are done by bus (4\% minibuses and coach), and $9 \%$ by non-motorised transport (Transport Malta [TM], 2010). Unsurprisingly, Maltese society is car-oriented (Malta Environment and Planning Authority [MEPA], 2003).

Preference for the car derives from its related convenience (European Commission, 2011).

Conversely, $86 \%$ of tourists use the bus when they visit Malta (Ministry for Tourism, 1999). Tourists visiting Malta use the bus mainly because there are few alternatives, but also because it is a cheap service (Attard, 2005). Additionally, in Malta driving takes place on the left-hand side of the road, which is an uncommon practice for most of the European countries from where tourists visiting Malta hail; this practice in addition to the high percentage of tourists who use the bus, lead to the assumption that tourists are discouraged from hiring a car.

The following sub-sections relate to Tables 1 and 2, which illustrate operational aspects, and the performance of the four bus service models that have operated in Malta over recent years. The first model lasted four decades. This was mainly a consequence of strong 
resistance to change from the operator. Eventually, political will led to a radical change resulting in the big bang approach to the bus service reform in 2011 (Attard, 2013). Model 2 summarises bus service operations in Malta following the reform. Two years later the service was nationalised (Model 3). Model four started operating in January 2015.

As indicated in Model 1 (Table 2) ticket sales reflected bus patronage, because each ticket sold reflected represented a bus user. This practice changed with Model 2 and continued with Models 3 and 4 (Table 2); tickets did not represent one trip any more. Patronage statistics are compiled by journey.

\subsection{The Operators}

During the late 1960s, the bus service in Malta operated under a liberalised market. Later, in the 1970s, bus owners (who were also bus drivers) coalesced, forming the Public Transport Association (PTA). This merger meant that the PTA became the sole operator of the bus service (Childs \& Sutton, 2008). Operator's licences were transferred from one generation to the other, and rarely became available for purchase on the market. This restriction within the market resulted in a monopoly of the bus service.

Table 1. The four models of bus service operations in Malta

\begin{tabular}{|c|c|c|c|c|}
\hline Model & 1 & 2 & 3 & 4 \\
\hline Duration & $1970 s-2011$ & $2011-2013$ & $2014-2015$ & 2015 - to date \\
\hline Type of Operation & Private Based Monopoly & Private Company & Nationalised Service & Private Company \\
\hline Operator & $\begin{array}{c}\text { Public Transport } \\
\text { Association (PTA) }\end{array}$ & Arriva Malta & Maltese Government & ALESA \\
\hline $\begin{array}{l}\text { Composition } \\
\text { of Operator }\end{array}$ & $\begin{array}{l}400 \text { bus owners-drivers } \\
\text { formed the PTA }\end{array}$ & $\begin{array}{l}\text { Arriva (Malta) } \\
\text { Consortium, composed } \\
\text { of Arriva International } \\
\text { Ltd (holding } 66.66 \% \\
\text { shares) and a local } \\
\text { entrepreneur, Tumas } \\
\text { Group (holding } 33.3 \% \\
\text { shares) }\end{array}$ & $\begin{array}{l}\text { Malta Public Transport } \\
\text { Same members of staff } \\
\text { amongst middle } \\
\text { management and bus } \\
\text { drivers }\end{array}$ & $\begin{array}{l}\text { Spanish bus company } \\
\text { took over the Malta Public } \\
\text { Transport with same staff, } \\
\text { and employing additional } \\
\text { members of staff }\end{array}$ \\
\hline Regulation & $\begin{array}{l}\text { Theoretically regulated by } \\
\text { government through the } \\
\text { various transport regulating } \\
\text { entities that changed } \\
\text { throughout the years }\end{array}$ & $\begin{array}{l}\text { Regulated by the local } \\
\text { transport authority, } \\
\text { Transport Malta. The } \\
\text { regulator followed a } \\
\text { service level agreement }\end{array}$ & $\begin{array}{l}\text { Regulated by Transport } \\
\text { Malta, an authority } \\
\text { running government's } \\
\text { transport policies }\end{array}$ & $\begin{array}{l}\text { Regulated by Transport } \\
\text { Malta }\end{array}$ \\
\hline Network Planning & $\begin{array}{l}\text { Hub-and-spoke principle } \\
\text { Main terminus - capital city } \\
\text { Valletta } \\
\text { Planned in an ad-hoc } \\
\text { reactive manner }\end{array}$ & $\begin{array}{l}\text { Widespread network } \\
\text { accessing peripheral } \\
\text { areas and introducing } \\
\text { changes } \\
\text { Eventually modified to } \\
\text { add the main radial } \\
\text { routes emerging from } \\
\text { Valletta }\end{array}$ & $\begin{array}{l}\text { Same network as } \\
\text { Model } 2\end{array}$ & $\begin{array}{l}\text { Initially same network as } \\
\text { Model } 2 \text {, to be extended } \\
\text { to } 40 \text { new and amended } \\
\text { routes }\end{array}$ \\
\hline $\begin{array}{l}\text { Existing and } \\
\text { promised fleet }\end{array}$ & $\begin{array}{l}508 \text { vehicles, including: } \\
166 \text { second-hand coaches } \\
\text { imported from the UK } \\
200 \text { custom-built buses by } \\
\text { bus owners, } 142 \text { modern } \\
\text { low floor purpose built King } \\
\text { Long buses }\end{array}$ & $\begin{array}{l}230 \text { new purpose built } \\
\text { King Long vehicles } \\
86 \text { vehicles that were } \\
\text { between } 2 \text { and } 7 \text { years } \\
\text { old } \\
13 \text { electric-hybrid } \\
\text { vehicles }\end{array}$ & $\begin{array}{l}\text { Sold } 81 \text { articulated } \\
\text { buses } \\
183 \text { vehicles from the } \\
\text { Arriva Malta service } \\
\text { Subcontracted } 42 \\
\text { vehicles ( } 26 \text { coaches, } \\
16 \text { minibuses) } \\
11 \text { new buses }\end{array}$ & $\begin{array}{l}230 \text { buses inherited from } \\
\text { Arriva Malta and the } \\
\text { Nationalised service, } \\
\text { including } 140 \text { additional } \\
\text { new vehicles }\end{array}$ \\
\hline $\begin{array}{l}\text { Comfort } \\
\text { (including } \\
\text { ambience } \\
\text { conditions) }\end{array}$ & $\begin{array}{l}\text { Characterised with high } \\
\text { floors, narrow entrances, } \\
\text { and narrow gangways }\end{array}$ & $\begin{array}{l}\text { Low floors for easy } \\
\text { access and air- } \\
\text { conditioned }\end{array}$ & $\begin{array}{l}\text { Low floors and } \\
\text { subcontracted vehicles } \\
\text { with high floors, narrow } \\
\text { entrances, and narrow } \\
\text { gangways }\end{array}$ & $\begin{array}{l}\text { Initially with } \\
\text { subcontracted vehicles to } \\
\text { be phased out; } \\
\text { Low floors }\end{array}$ \\
\hline Information & $\begin{array}{l}\text { Internet: summer and winter } \\
\text { schedules provided on the } \\
\text { PTA website } \\
\text { On boards and information } \\
\text { kiosks in main termini }\end{array}$ & $\begin{array}{l}\text { Internet: online journey } \\
\text { planner } \\
\text { On board: destination } \\
\text { and 'next stop' } \\
\text { electronic displays } \\
\text { At major interchanges: } \\
\text { real-time information } \\
\text { On all bus stops: flag } \\
\text { poles with schedules }\end{array}$ & $\begin{array}{l}\text { Internet: online journey } \\
\text { planner and google } \\
\text { maps } \\
\text { On board: destination } \\
\text { and 'next stop' } \\
\text { electronic displays } \\
\text { At major interchanges: } \\
\text { real-time information } \\
\text { On all bus stops: flag } \\
\text { poles with schedules }\end{array}$ & $\begin{array}{l}\text { Internet: online journey } \\
\text { planner and google maps } \\
\text { On board: destination and } \\
\text { 'next stop' electronic } \\
\text { displays } \\
\text { At major interchanges: } \\
\text { real-time information } \\
\text { On all bus stops: flag } \\
\text { poles with schedules } \\
\text { Smartphone app. }\end{array}$ \\
\hline
\end{tabular}




\begin{tabular}{|c|c|c|c|c|}
\hline $\begin{array}{l}\text { Compliance with } \\
\text { Euro Emission } \\
\text { Standards }\end{array}$ & Minority of fleet, Euro III & Euro V & $\begin{array}{l}\text { Majority Euro V, } \\
\text { minority no standards }\end{array}$ & $\begin{array}{l}\text { Majority Euro V and Euro } \\
\text { VI, initially minority no } \\
\text { standards }\end{array}$ \\
\hline $\begin{array}{l}\text { Contractual } \\
\text { Obligations }\end{array}$ & $\begin{array}{l}\text { Non-existent contractual } \\
\text { obligations. Two main } \\
\text { agreements - } 1995 \text { and } \\
2000\end{array}$ & $\begin{array}{l}\text { Service level } \\
\text { agreement bound by } \\
\text { rigid contract (10-year } \\
\text { contract), determining } \\
\text { specific service quality } \\
\text { characteristics e.g. } \\
\text { fleet, comfort, } \\
\text { information }\end{array}$ & $\begin{array}{l}\text { No contract - } \\
\text { presumably, continued } \\
\text { to refer to the contract } \\
\text { of Model } 2 \text {, adopting a } \\
\text { relaxed approach (i.e. } \\
\text { no penalties) }\end{array}$ & $\begin{array}{l}\text { Unknown. In December } \\
2014 \text {, the Minister } \\
\text { promised that the contract } \\
\text { would be tabled in } \\
\text { Parliament. In February } \\
2016 \text { a hard copy of the } \\
\text { contract has been tabled } \\
\text { in Parliament }\end{array}$ \\
\hline Subsidisation & $\begin{array}{l}\text { Since } 1995 \text {. } \\
\text { By } 2010 \text { the subsidy } \\
\text { reached } € 9.6 \text { million (US } \$ 11 \\
\text { million) }\end{array}$ & $\begin{array}{l}\text { Bid for } € 10.25 \text { million } \\
\text { (US } \$ 11.42 \text { million) } \\
\text { Negotiated } € 6.2 \text { million } \\
\text { (US } \$ 7 \text { million). By } 2013 \\
\text { asked for a subsidy } \\
\text { increase of } € 45 \text { million } \\
\text { (US } \$ 50 \text { million) }\end{array}$ & $\mathrm{N} / \mathrm{A}$ & $\begin{array}{l}€ 29 \text { million (US } \$ 32 \\
\text { million) }\end{array}$ \\
\hline
\end{tabular}

The PTA was bound to deliver a service by two main agreements. The 1995 agreement secured an increase in fare prices, additional services to the network, the introduction of bus driver uniforms, upgrading of some of the old buses, ticketing machines on all vehicles, and a change of colour of the vehicles from green to yellow and orange. The year 2000 agreement imposed three social obligations on the PTA. These were to operate the bus service, to carry bus passengers, and to provide fixed tariffs (Sutton, 2000).

Table 2. Performance aspects of the four models of bus service operations in Malta

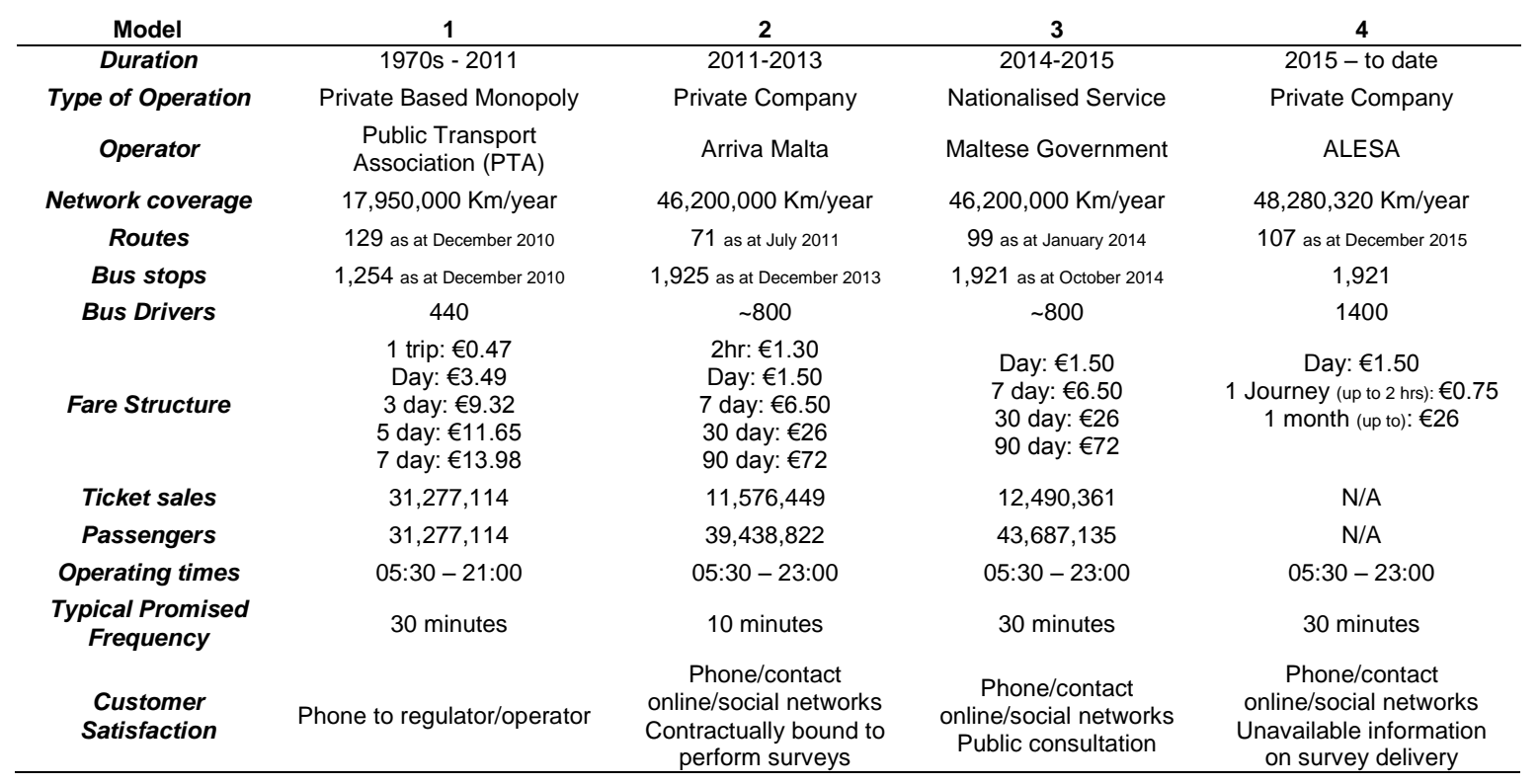

In 2008, Government launched the public transport White Paper (Ministry of Infrastructure Transport and Communications [MITC], 2008). The main aim of this white paper was to achieve a modal shift, from car use to bus use. The White Paper listed seven objectives that were expected to be met through the bus service reform. These were (i) improve network planning; (ii) change the bus fleet to comply with EU emission standards; (iii) remove the exclusivity of rights to operate; (iv) apply a roster system following EU regulations; (v) provide an efficient government subsidy; (vi) provide information to customers; and (vii) increase and enforce regulation (MITC, 2008). 
After publishing the White Paper, in 2008, the Government touted widely the high-level specifications of how the new bus service would operate. This approach to information dissemination raised public expectations (Attard, 2012).

A competitive tendering approach was selected as the contracting model for the procurement of the bus service. Eventually, Arriva Malta Consortium won the bid (Table 1). The new bus service started operating on the $3^{\text {rd }}$ July 2011 with all the changes implemented at once - as a big bang.

Arriva Malta failed to comply with the contractual agreement on several different levels (explored in section 5). The company suffered with over $€ 70$ million (US\$78 million) in debts. The failure of the bus service reform (Model 2) contributed partly to the Government losing the election in 2013. To avoid liquidation the newly elected Government intervened, and bought the bus company at a nominal value of $€ 1$ (US\$1.11) (Dalli, 2014).

In January 2014, the Government became the operator of the bus service (Model 3). Nationalisation meant that government would be the operator and regulator of the bus service. Such operations were temporary. The new bus company became Malta Public Transport (Table 1). During this time, in January 2014, Government invited an expression of interest "for the provision of scheduled bus services in Malta and Gozo" (Transport Malta, 2014). Unsurprisingly, having given the lowest financial offer, ALESA was the preferred option (Model 4) (Micallef, 2014 and Mizzi, 2014). Government negotiated the service with the Spanish operator behind closed doors. Eventually, on the $8^{\text {th }}$ January 2015, ALESA took over the bus service. The new bus company maintained the name Malta Public Transport (Sansone, 2014).

A recurring issue in all the four models was the cost of operations. For Model 1 (PTA) subsidisation covered wages, fuel, maintenance, and lower fares for pensioners and students. In Models 2 (Arriva Malta), and 4 (ALESA), subsidisation includes but is not restricted to fuel costs, and lower fares for pensioners and students.

\subsection{Regulation}

The first Model in Table 1 shows that the State officially regulated the bus service, but it granted several operating privileges to the PTA. These conditions ensured that the association was the sole operator of the bus service. The State also granted the licence holders' exclusive rights to operate, it prohibited direct competition in the sector by restricting market access, restricted bus importation by other companies, and prohibited other organisations from operating a service along set routes, on a schedule, or that picked up passengers from bus stops (Xuereb, 2001).

With the bus service reform (Model 2), Government through the regulating authority, Transport Malta, continued to regulate the bus service. However, this time the regulator could make use of the service level agreement. A contractual agreement bound Arriva Malta to deliver the agreed level of service. Failure to deliver meant that the regulator could impose fines on the operator.

In Model 3, Government became the operator and regulator of the bus service. This situation was temporary until the selection of the new private operator. Following this, in Model 4, Transport Malta continued to regulate the bus service. This meant that throughout the four 
models, the regulating authority regulated the network, fare structure (Table 2), and the operating frequency of the bus service.

Initially, for Model 2 (Arriva Malta) the fare structure was different for tourists. They had to pay a higher fare than Maltese residents did, which was considered discriminatory. Following complaints by the European Members of Parliament, the European Commission launched formal legal proceedings against the Maltese government about this issue (Vassallo, 2011). The European Union executive decided that the bus fare infringed EU law, and the Maltese Government was asked to rectify this illegality, who eventually complied (Camilleri, 2013).

Since negotiations between Government and ALESA (Model 4) occurred behind closed doors, the contractual agreement remained unknown for a year until January 2016. The contractual agreement binds ALESA to deliver the agreed level of service.

\subsection{Network Planning and Operations}

Under Model 1 (Table 1) planning took place in 'an ad-hoc reactive manner'; for instance by reducing headway or by removing specific departures according to need (Childs \& Sutton, 2008). Model 2 radically changed the planning and operations of the network. As indicated in Table 1, the new network provided accessibility to the peripheral areas, and introduced interchanges.

The network later changed. Most routes that formed part of the old network were reintroduced on top of the new network. Models 3 and 4 continued to operate with the same network. However, with Model 4 some routes are expected to improve. As indicated in Table 2 the network coverage increased nearly three times as much from Model 1 (PTA) to Model 4 (ALESA).

To obtain this increase in network coverage the number of routes also increased from the first to the fourth model. Arriva Malta's model (Model 2) had a substantial increase in network coverage from Model 1 with the least amount of bus routes amongst the four models (Table 2). This suggests that there was more utilisation of the fleet on the road at any one particular time.

Although the PTA (Model 1) had 508 vehicles, these operated on a day-in day-out basis, hence, in one day of operations there would be half the amount on the road. Since Arriva Malta (Model 2), this method of operation has changed to have as much vehicles servicing the network as possible. Hence, while in the first model the vehicles could be maintained on the day off, the other three models became more susceptible to wear-and-tear issues that were frequently witnessed by the customers (as is explored in section 5).

As seen in Table 2, operating times increased following the reform (Models 2 to 4). Night services were promised, however, to date these are only restricted to entertainment areas on weekends. Arriva Malta (Model 2) also promised the lowest maximum waiting times.

Following time-related issues, Models 3 and 4 increased waiting times to a minimum of 30 minutes, as per Model 1.

\subsection{The Fleet, Information, and Customer Satisfaction}

The fleet changed considerably throughout the years, and across the four models (Table 1). The major change occurred with Model 2, where the old buses that were a characteristic of 
Malta were removed, and a new environmental-friendly and more accessible fleet was introduced. Eventually, the fleet degraded again, because old vehicles were sub-contracted to address the time-related issues. This problem persisted into Model 3, but started to improve again in Model 4. ALESA started importing new EU environmental compliant vehicles.

Similarly, the quality of information changed throughout the four model scenarios. Online information was available as seen in Table 1. Following the bus service reform (Models 2 to 4) a journey planner became available online. Information increased for the bus service users on board the bus, and on the bus stops.

As claimed by government (MITC, 2008), Model 1 (PTA) was not customer-oriented. There was no official obligation to run customer satisfaction surveys, and customers could only complain directly by phoning the regulator or the operator, or indirectly through newspapers. Since the reform, models 2 and 4 contractually bound the operators to perform customer satisfaction surveys, which, however, are not available to the public. Research, however shows that following the reform, Arriva Malta (Model 2) service suffered from time-related issues (Attard, 2013 and Bajada, 2015).

\section{Research Methodology}

Thirty-four in-depth semi-structured interviews (17 Maltese residents and 17 tourists) were conducted to explore people's attitudes towards the bus service in Malta. Qualitative sampling works with small population samples, and does not seek statistical significance (Miles \& Huberman, 1994). The interviews were collected between July 2014 and October 2014, while Model 3 was in operation, and the process to move to Model 4 had begun.

The Maltese resident participants were contacted through initial contacts, and the tourist participants were intercepted in three localities renowned with tourists in Malta (Valletta, St Julian's/Sliema area and St Paul's Bay). The Maltese citizen participants included bus users and car users. Participants L5, L6 and L15 were bus users during Model 1, but changed to car use after the implementation of the reform.

In both cases of population sample selection, care was given to balance the gender and age groups; although for the case of the Maltese participants it was more difficult since contact relied on the initial contacts. Each interview lasted approximately 30 minutes. Tables 3 and 4 illustrate the basic information about the interviewees. Each interview was recorded and then transcribed.

The interviews were semi-structured; in that all participants were asked the same eight questions, (this research forms part of an over-arching study). From the eight questions, the following two questions are relevant for the purpose of this paper.

Question 1: What is your opinion about the bus service in Malta?

Question 2: How would you describe the bus service quality? Can you recall some experiences?

Prompts were used throughout the interviews, to keep the interviewees talking (Leech, 2003). Some of the participants, both Maltese and tourists, were familiar with Models 1 to 3 . A few were aware of the impending Model 4. 
Table 3. Basic information regarding the interviewees - Maltese residents

\begin{tabular}{|c|c|c|c|c|c|c|c|c|}
\hline Code & Gender & Age & Occupation & Household Type & District of Origin & District Destination & $\begin{array}{l}\text { Transport Mode } \\
\text { Mostly Used }\end{array}$ & Car Owner \\
\hline L1 & Female & $60+$ & Housewife & Terraced House & Northern & Northern Harbour & Car & No \\
\hline L2 & Female & $60+$ & Retired & Flat & Northern Harbour & Western & Bus & No \\
\hline L3 & Female & $60+$ & Housewife & Maisonette & Western & Southern Harbour & Car & No \\
\hline L4 & Male & $31-40$ & Professional & Maisonette & Northern Harbour & Southern Harbour & Car & Yes \\
\hline L5 & Female & $31-40$ & Professional & Penthouse & Northern & Southern Harbour & Car & Yes \\
\hline L6 & Female & $31-40$ & Professional & Terraced House & Southern Harbour & Northern Harbour & Car & Yes \\
\hline L7 & Female & $21-30$ & Service workers & Maisonette & Western & Western & Car & Yes \\
\hline L8 & Female & $51-60$ & Clerks & Maisonette & Western & Southern Harbour & Car & Yes \\
\hline L9 & Male & $31-40$ & Professional & Flat & Northern Harbour & Southern Harbour & Bus & No \\
\hline L10 & Female & $60+$ & Retired & Maisonette & Northern Harbour & Northern Harbour & Bus & No \\
\hline L11 & Female & $31-40$ & Professional & Maisonette & Southern Harbour & Southern Harbour & Bus & Yes \\
\hline L12 & Male & $41-50$ & Professional & Terraced House & Southern Harbour & Southern Harbour & Bus & Yes \\
\hline L13 & Female & $60+$ & Retired & Maisonette & Northern Harbour & Northern Harbour & Car & No \\
\hline L14 & Female & $60+$ & Retired & Maisonette & Northern Harbour & Northern & Bus & No \\
\hline L15 & Male & $31-40$ & Professional & House of Character & Southern Harbour & Southern Harbour & Car & Yes \\
\hline L16 & Male & $60+$ & Retired & Maisonette & Northern & Northern & Bus & Yes \\
\hline L17 & Female & $60+$ & $\begin{array}{c}\text { Technicians \& } \\
\text { associate professionals }\end{array}$ & Flat & South Eastern & Northern Harbour & Bus & Yes \\
\hline
\end{tabular}

The transcripts were analysed by means of a Computer-Assisted Qualitative Data Analysis Software (CAQDAS), Atlas.ti version 6.2 (Atlas.ti, 2013) using a thematic analysis approach. This is a method for identifying recurring themes from data (Braun \& Clarke, 2006). The themes were assigned through unrestricted coding, allowing an inductive approach to interpreting the themes. Table 5 lists the six themes that emerged from the thematic analysis, and gives a brief description of each. As shown in Table 5, four of the themes (time, information, fare, and impact on the environment) that emerge from the analysis, form part of the eight service quality characteristics mentioned in section 2.2.2. These themes are analysed in more detail in section 5 .

Table 4. Basic information regarding the interviewees - Tourists

\begin{tabular}{|c|c|c|c|c|c|c|c|c|}
\hline Code & Gender & Age & Reason for Visiting & $\begin{array}{c}\text { Been to Malta } \\
\text { before } 2011\end{array}$ & Mode Use & Length of Stay & $\begin{array}{c}\text { Type of } \\
\text { Accommodation }\end{array}$ & $\begin{array}{c}\text { District of } \\
\text { Accommodation }\end{array}$ \\
\hline $\mathrm{T} 1$ & Male & $21-30$ & Business & Yes & Bus & $21+$ nights & Self-Catered Apartment & Northern \\
\hline $\mathrm{T} 2$ & Male & $21-30$ & Holiday & Yes & Bus & $8-14$ nights & Friends' House & Northern \\
\hline T3 & Female & $21-30$ & Business & Yes & Bus & $21+$ nights & Self-Catered Apartment & Northern \\
\hline $\mathrm{T} 4$ & Female & $21-30$ & Education & No & Bus & $21+$ nights & Host Family & Northern \\
\hline T5 & Male & $21-30$ & Business & No & Bus & $21+$ nights & Self-Catered Apartment & Northern Harbour \\
\hline T6 & Male & $41-50$ & Business & No & Bus & 15-21 nights & Self-Catered Apartment & Northern Harbour \\
\hline $\mathrm{T7}$ & Female & $31-40$ & Holiday & No & Bus & 4-7 nights & 3-Star Hotel & Northern Harbour \\
\hline T8 & Male & $21-30$ & Holiday & No & Bus & 4-7 nights & 3-Star Hotel & Northern Harbour \\
\hline T9 & Female & $60+$ & Holiday & No & Bus & 4-7 nights & 3-Star Hotel & Southern Harbour \\
\hline $\mathrm{T} 10$ & Female & $21-30$ & Holiday & No & Bus & 4-7 nights & Hostel & Northern Harbour \\
\hline $\mathrm{T} 11$ & Male & $51-60$ & Holiday & Yes & Bus & 4-7 nights & Self-Catered Apartment & Southern Harbour \\
\hline $\mathrm{T} 12$ & Male & $60+$ & Holiday & Yes & Bus & 4-7 nights & 3-Star Hotel & Northern Harbour \\
\hline $\mathrm{T} 13$ & Male & $31-40$ & Holiday & No & Bus & 15-21 nights & Friends' House & Northern \\
\hline T14 & Female & $60+$ & Holiday & Yes & Bus & 15-21 nights & 4-Star Hotel & Northern \\
\hline $\mathrm{T} 15$ & Female & $51-60$ & Holiday & Yes & Bus & $15-21$ nights & Self-Catered Apartment & Northern \\
\hline T16 & Male & $21-30$ & Education & No & Bus & $21+$ nights & Self-Catered Apartment & Northern Harbour \\
\hline T17 & Female & $60+$ & Holiday & Yes & Bus & $21+$ nights & Self-Catered Apartment & Northern \\
\hline
\end{tabular}

Table 5. The six themes that emerged from the semi-structured interviews

\begin{tabular}{|c|c|}
\hline Main Themes & Description \\
\hline Time & $\begin{array}{l}\text { Punctuality issues and unreliability. Amount of time spent waiting for the bus, travelling by bus, and } \\
\text { waiting (on the bus) for people to pay the driver }\end{array}$ \\
\hline Information & $\begin{array}{l}\text { Includes schedules about the bus service both online, on-board the fleet and on bus stops and } \\
\text { interchanges }\end{array}$ \\
\hline Bus Drivers & Men and women driving the bus, often their behaviour influences the experience of the customers \\
\hline Fare & The fee paid for a journey or for an amount of journeys, reflecting the fare structure \\
\hline Fleet & The vehicles used to provide the bus service \\
\hline Impact on the Environment & Pollution emitted from the fleet, particularly air and noise pollution. \\
\hline
\end{tabular}




\section{Analysis}

With the radical change Model 1 to Model 2, Arriva Malta targeted an increase in bus passengers by $54 \%$ by the end of the 10-year contract period, and a reduction in the carbon footprint of Malta's bus operation by $15 \%$ by 2017 over 2011 estimates. The promised investment was $€ 47$ million (US $\$ 52$ million) (Times of Malta Online, 2010). None of these promises materialised. The analysis refers to a combination of both Maltese residents and tourists' comments. Table 6 refers to the participants' quotations that relate to each theme, which are explored in the following sub-sections.

Table 6. Participants' quotations by theme

\begin{tabular}{|c|c|c|c|c|}
\hline Theme & \# & Interviewee & Quotations & $\begin{array}{l}\text { Reference to } \\
\text { Bus Service }\end{array}$ \\
\hline \multirow{10}{*}{ Time } & 1 & L1 & "...they need to improve the times, more frequent times." & Model 3 \\
\hline & 2 & $\mathrm{~T} 1$ & $\begin{array}{l}\text { "...all the buses came full up...so it took us like ... one hour to wait and the buses } \\
\text { passed... but they didn't stop because they all were full up..." }\end{array}$ & Model 3 \\
\hline & 3 & T3 & $\begin{array}{l}\text { "...Maltese people don't take the bus because they know that it is going to take them so } \\
\text { long so they try to avoid it." }\end{array}$ & Model 3 \\
\hline & 4 & L3 & $\begin{array}{l}\text { "We were much better when we were in a worse situation. Before, when I used to go on } \\
\text { the bus stop at } 2 \mathrm{pm} \text {, I was sure that the bus would pass..." }\end{array}$ & Model 1 \\
\hline & $\begin{array}{l}5 \\
6\end{array}$ & $\begin{array}{l}\text { T1 } \\
\text { L5 }\end{array}$ & $\begin{array}{l}\text { "From my point of view they were more reliable..." } \\
\text { "I started using my car because of the unreliability... unreliability was an issue" }\end{array}$ & $\begin{array}{l}\text { Model } 1 \\
\text { Model } 2\end{array}$ \\
\hline & 7 & $\mathrm{~T} 1$ & $\begin{array}{l}\text { "...I think the service improved, since the first time I came here... They're not perfect, but } \\
\text { they are better than they were, for example with punctuality" }\end{array}$ & Models 1 and 3 \\
\hline & 8 & L9 & $\begin{array}{l}\text { "The quality of the fleet is going from bad to worse. We removed the bendy buses and } \\
\text { re-introduced old vehicles from other companies..." }\end{array}$ & Model 3 \\
\hline & 9 & L9 & "...and each time they ask the driver whether the bus goes to Valletta." & Model 3 \\
\hline & 10 & $\mathrm{~T} 13$ & "...tourists have many questions for the driver, where are the museums and all this..." & Model 3 \\
\hline & 11 & T4 & $\begin{array}{l}\text { "... if you trust the schedule...they said that the buses .... are not reliable, and you have } \\
\text { to be there before, and you have to wait for a long time" }\end{array}$ & Model 3 \\
\hline \multirow[t]{9}{*}{ Information } & 12 & L2 & $\begin{array}{l}\text { "...the information office in Valletta. I used to ask them for information there... They give } \\
\text { you brochures if you ask" }\end{array}$ & Models 2 and 3 \\
\hline & 13 & L9 & $\begin{array}{l}\text { "...electronic signage indicated the wrong information. For instance one of the major } \\
\text { problems was the direction...this led to confusion, especially for tourists..." }\end{array}$ & Models 2 and 3 \\
\hline & 14 & L6 & $\begin{array}{l}\text { "I heard that the summer schedule took a long time to be published, and the service } \\
\text { continued to operate with the winter schedule" }\end{array}$ & Model 3 \\
\hline & 15 & T5 & "...I heard that we pay only $€ 1.50$ for a day, for all the trips..." & Model 3 \\
\hline & 16 & L13 & $\begin{array}{l}\text { "...a driver and a passenger started fighting....and I was asked to serve as a witness in } \\
\text { court." }\end{array}$ & Model 1 \\
\hline & $\begin{array}{l}17 \\
18\end{array}$ & $\begin{array}{l}\text { T1 } \\
\text { T3 }\end{array}$ & $\begin{array}{l}\text { "...he (the driver) was shouting at me on the bus..." } \\
\text { "..they were a bit rude..." }\end{array}$ & $\begin{array}{l}\text { Model } 1 \\
\text { Model } 1\end{array}$ \\
\hline & 19 & $\mathrm{~T} 1$ & $\begin{array}{l}\text { "....they are better than they were...it's more a professional service... better than the bus } \\
\text { drivers of the old service...I trust them more because of the company image..." }\end{array}$ & Models 2 and 3 \\
\hline & 20 & L2 & $\begin{array}{l}\text { "... a lot of the bus drivers do not engage } 100 \% \text { of their efforts to deliver a good } \\
\text { service..." }\end{array}$ & Model 3 \\
\hline & 21 & L2 & $\begin{array}{l}\text { "These (drivers) brake a lot and suddenly. Recently, I fell on my knees (on the bus) and } \\
\text { it hurt. ... It's not the first time that I saw people fall because of the sudden braking." }\end{array}$ & Model 3 \\
\hline \multirow[t]{4}{*}{ Bus Drivers } & 22 & T4 & $\begin{array}{l}\text { "...they are crazy, the way they drive, because in my opinion they drive too fast, and } \\
\text { when they drive past a corner they don't stop, they just continue driving, and they don't } \\
\text { care if you are sitting, or if you are standing in the bus. So it's not really safe either." }\end{array}$ & Model 3 \\
\hline & 23 & T7 & "...sometimes they are a bit overcrowded, and the bus drivers can seem a bit stressed". & Model 3 \\
\hline & 24 & T5 & $\begin{array}{l}\text { "...it's very cheap...I only pay } € 1.50 \text {, and I don't need to take the taxi, because it's too } \\
\text { expensive" }\end{array}$ & Model 3 \\
\hline & $\begin{array}{l}25 \\
26\end{array}$ & $\begin{array}{l}\mathrm{L} 1 \\
\mathrm{~L} 4\end{array}$ & $\begin{array}{l}\text { "...the drivers did not give change because they were tourists..." } \\
\text {...I remember tourists were at times charged more..." }\end{array}$ & $\begin{array}{l}\text { Model } 1 \\
\text { Model } 1\end{array}$ \\
\hline \multirow[t]{3}{*}{ Fare } & 27 & $\mathrm{~T} 17$ & $\begin{array}{l}\text { "And I think it's cheaper now than it did in the Arriva service. We always used the day } \\
\text { return ticket. I seem to recall it cost about } € 2.60 \text {, and it's } € 1.50 \text { now." }\end{array}$ & Model 2 and 3 \\
\hline & 28 & L13 & $\begin{array}{l}\text { "... used to be afraid of the bendy buses...I used to avoid the bendy buses because I } \\
\text { was afraid" }\end{array}$ & Model 2 \\
\hline & 29 & T3 & $\begin{array}{l}\text { "...the bigger buses...they were a bit old, and some of them caught fire. This is very } \\
\text { scary." }\end{array}$ & Model 2 \\
\hline Fleet & 30 & T9 & $\begin{array}{l}\text { "The bus service is good, except when it's very busy. ... once when it was crowded we } \\
\text { got robbed } € 100 . "\end{array}$ & Model 3 \\
\hline \multirow{4}{*}{$\begin{array}{l}\text { Impact } \\
\text { on the } \\
\text { Environment }\end{array}$} & 31 & T5 & $\begin{array}{l}\text { "I think the most negative part is that they use the air conditioner, I think it's on Freon, } \\
\text { and maybe they could destroy the Ozone, that's it." }\end{array}$ & Model 3 \\
\hline & 32 & $\mathrm{~T} 10$ & $\begin{array}{l}\text { "...they're (the buses) always running on air conditioning...this is not the most } \\
\text { environmental friendly procedure..." }\end{array}$ & Model 3 \\
\hline & 33 & $\mathrm{~T} 10$ & $\begin{array}{l}\text { "...also I get the feeling that all the buses have been acquired from all different parts of } \\
\text { the world...some of the older buses would probably be not so environmental friendly..." }\end{array}$ & Model 3 \\
\hline & 34 & L17 & $\begin{array}{l}\text { "... when the Arriva service was going to be introduced...They had distributed a lot of } \\
\text { leaflets. Still I expected better quality service than what they provided..." }\end{array}$ & Model 2 \\
\hline \multirow{3}{*}{ Expectations } & 35 & L9 & $\begin{array}{l}\text { "I'm not confident, I mean we changed the service radically... It wasn't exactly what we } \\
\text { were expecting... we need to go through another transitional period... Let's hope for the } \\
\text { best. If I were to rate my confidence in the service out of } 10, \text { I would give it a } 5 . "\end{array}$ & Model 2 to Model 4 \\
\hline & 36 & T6 & "...not always on time, but you cannot expect that (it's always on time)..." & Model 3 \\
\hline & 37 & $\mathrm{~T} 13$ & $\begin{array}{l}\text { "...and now of course, because it's tourist high season, I understand that sometimes it's } \\
\text { late. You would expect it, because tourists have many questions for the driver..." }\end{array}$ & Model 3 \\
\hline
\end{tabular}




\subsection{Time}

The local interviewees, as well as the tourists showed their concerns regarding the time spent waiting or travelling by bus (Table 6, \#1 and \#2). Tourists generally did not mind the long journey but voiced their concerns for the local commuters (Table 6, \#3).

According to the participants, Model 1 was generally considered a good service with regard to punctuality and reliability (Table 6, \#4 and \#5). As stated in section 3.4, the problems started with Model 2. The bus system underwent a radical change that included maximum waiting times, and increased route lengths. This change together with the reduced number of vehicles (Table 1), and traffic congestion led to timing related issues. The main issues concerned punctuality and reliability. This situation led Maltese participants to express their preference to the old bus service (Model 1) (Table 6, \#4 and \#6).

As indicated in Table 1, in Model 3 the Government tried to improve the timing issues by increasing the fleet using sub-contracted vehicles. Participant T1 observed the improvement regarding punctuality (Table $6, \# 7$ ). The downside to this approach was that not all of these newly introduced vehicles were accessible and compliant with EU environmental standards. In fact, participant L9 (Table 6, \#8) expressed his concern that the fleet was worsening. This situation continued with Model 4, however, ALESA promised to import new vehicles that were Euro V and Euro VI compliant (Table 1).

\subsection{Information}

Despite the fact that as indicated in Table 1 information had to improve, the participants felt that information was restricted, although there were improvements. The interview participants observed that in all the first three models, other bus users asked the driver questions (Table 6, \#9 and \#10), implying that other customers suffered from a wasted in-vehicle time.

With the Arriva Malta bus service (Model 2), information improved. The participants mentioned issues of trust when referring to the schedules (Table 6, \#11). It seems, however, that Maltese participants still obtained information from leaflets, or from what they heard from family members or friends (Table 6, \#12).

Electronic information on-board vehicles indicated the next bus stops, and major and secondary interchanges included electronic displays. As reported by L9 (Table 6, \#13), the problem with this electronic information was that the I.T system did not work properly on day one of operations. Some bus stop names on-board the vehicles indicated Chinese locations (the fleet was custom made in China), and electronic displays on bus stops failed to show the bus numbers that were due (Jarosz, 2011).

This problem persisted into the nationalised service (Model 3), although in this model some major interchanges showed the correct time when the next buses were due. In Model 3 online information also included a journey planner hosted on Google Maps (Google Maps, 2015). Information related issues however, persisted, and the participants still relied on what they heard (Table 6, \#14 and \#15). 


\subsection{Bus Drivers}

The participants reported that in Model 1 the bus drivers had a negative attitude, and lack of customer care (Table 6, \#16 to \#18). This was reported in several instances (MITC, 2008; Lidstone, 2011; Attard, 2013 and Bajada, 2015).

Participant T1 stated that in Models 2 and 3 the service became more professional, and the bus drivers were better than in the old service (Model 1) (Table 6, \#19) (Jarosz, 2011).

Additionally, the bus service reform (Model 2), improved the working hours of the bus drivers. They started to work a 40-hour week, thus following EU law (Jarosz, 2011).

In Model 2 however, new issues regarding bus drivers reportedly arose. At the end of the operation of Arriva Malta (Model 2) and into Model 3, bus driver attitude, and their driving manner started degrading (Table 6, \#21 and \#22). They drove aggressively, and braked suddenly, participant L2 fell on her knees on board the bus and hurt herself. Undoubtedly, bus users felt uncomfortable, and unsafe on the bus.

The participants revealed another issue that is indirectly linked to bus drivers, that of overcrowding on the buses. Participant T7 (Table 6, \#23) said that the bus drivers seemed stressed when there were too many people on board the bus.

\subsection{Fare}

Participants considered that the fare was cheap. Additionally, after the Model 2 over-charging of bus fares by bus drivers ceased as tickets had to be issued through a ticketing machine on board the bus, and bus drivers were no longer interested in the revenue from passengers since they were no longer the owners of the service.

Participant T5 (Table 6, \#24) stated that the service was cheap in Model 3. Under the PTA operations, (Model 1) Malta's bus service was renowned to be the cheapest amongst other European countries (Attard, 2005). As indicated in Table 2, the fare structure under Arriva Malta (Model 2) was similar to that in the nationalised service (Model 3), and ALESA (Model 4). Hence, the fare remained relatively cheap, as confirmed by participant T5 (Table 6, \#24).

Participant T17 (Table 6, \#27) indirectly mentioned the issue of fare discrimination mentioned in section 3.2. He observed that during the nationalised service (Model 3) the fare was cheaper than under the Arriva Malta (Model 2) service.

On recalling the bus service provided by the PTA (Model 1), both the local participants and tourists described situations in which they either were robbed by the bus driver, or witnessed a similar situation. Bus drivers often failed to give the proper change to tourists (Table 6, \#25 and \#26).

This behaviour improved in Models 2 and 3 and has further improved in Model 4. In April 2015, ALESA introduced a new fare card, 'tallinja card'. It is a pay-as-you-go card that allows passengers to top-up online before using the bus service. With this new service the fare structure changed in July 2015, making them more expensive if a ticket is bought on the bus (Malta Public Transport, 2015). The aim of this card is to discourage people from buying tickets from the driver, thus helping reducing travel time. This initiative led to 240,000 personalised 'tallinja' smartcard registrations (Izatt, 2015). 


\subsection{Fleet}

As indicated in Table 1, Model 1 operated with an old fleet. The major issue for the local participants, particularly elderly people, was that the bus was often inaccessible, because of the high steps (MITC, 2008). Most of the tourist participants liked the old buses, because they had character, and a bus ride was described as an adventure. Tourists T15 and T17 amusingly described the buses as the "bone shakers".

In Model 2, the fleet improved in terms of accessibility. The Arriva Malta service introduced articulated vehicles. These were second-hand vehicles, imported from London. The vehicles were poorly maintained, which led to most of these vehicles catching fire (Times of Malta Online, 2014). Both local and tourist participants mentioned occasions when the articulated buses caught fire, and expressed their fear and state of insecurity when using them. Some of the local participants dreaded them to an extent that they preferred to wait for the next bus that was not an articulated vehicle (Table 6, \#28 and \#29). In the nationalised service (Model 3), Government removed the articulated vehicles, and ALESA (Model 4) did not introduce them.

Another issue was on-board accessibility. Overcrowding on the buses (as mentioned in section 5.3) in major touristic areas led tourists to suffer several bad experiences. Some examples include missing the bus stop because they could not alight the bus, as reported by participant T15 they "couldn't fight the way through the people"; as well as being robbed on the bus (Table 6, \#30).

\subsection{Impact on the Environment}

In comparison to the PTA vehicles (Model 1), the buses of Arriva Malta (Model 2) improved in terms of pollution. In fact, Bajada (2015) reports that an estimated $44 \%$ of Maltese residents agreed that the impact on the environment was rated the best on a five point Likertscale. Attard's (2013) findings resonate. This resulted mainly from the requirements imposed on Arriva Malta to operate with Euro $V$ vehicles. Two tourists however, mentioned that since the new buses were air-conditioned they emitted more pollution. Most of the new buses still ran on fossil fuels (Table 6, \#31 and \#32).

Government had to increase the fleet to improve time related issues (refer to section 5.1). These additional vehicles were a source of pollution, because they did not comply with the European emission requirements. Consequently, as observed by participant T10 (Table 6, \#33) Model 3 experienced downgrading in this matter.

With Model 4, this situation improved as ALESA operates with Euro V and Euro VI compliant vehicles. The Euro VI buses are reducing the amount of $\mathrm{CO}_{2}$ emissions by 18 tonnes annually (Izatt, 2015).

\subsection{Expectations}

As discussed in the literature review, section 2.2.1, it is necessary to acknowledge expectations, but they should be considered with caution. Consequently, the theme 'expectations' is not listed in Table 5. The thematic analysis, however, indicates that the interview participants had expectations of the bus service. Interestingly, the expectations of the two types of stakeholders differed. 
Maltese residents' expectations revolved round the definition by Teas (1993), "what the service should offer". Their expectations were formed on Model 2 (the promised Arriva Malta service), and Model 4 (the promised ALESA service). In their discussion on expectations, the participants mentioned 'improvement', 'service quality', and 'disappointment' (Table 6, \#34 and \#35).

The tourists did not seem to have prior expectations. Their expectations derived from their experience of the bus service. Consequently, when revealing their expectations they seemed to justify the delay of the bus service, and the over-crowdedness on the bus (Table 6, \#36 to \#37).

\section{Discussion and Conclusion}

This paper provides insights on how the four models of operation influenced the service quality, as well as the stakeholders' attitudes towards the bus service. The participants' responses indicate that they were not particularly interested in the market structure or selection process of the operator; they were interested in the service quality that they encounter. Hence, service quality is a key element in bus service operation, irrespective of the market structure in which operations take place. The following sub-sections refer to the highlights, and implications for bus service improvement from the findings.

\subsection{Regulation}

Regulation is an important element in bus service operations. The findings support this statement regarding two criteria, the fare structure, and impact on the environment.

The participants appreciated what they considered to be a cheap bus fare, which was regulated throughout the four models. After the reform, Model 2 improved the impact on the environment, as the fleet was initially required to comply with EU regulations on Euro $\mathrm{V}$ vehicles. The service deteriorated once more with sub-contracting of vehicles that were not compliant with EU regulations in Models 2 and 3. Model 4, however, improved the issue with the fleet once more, as it started working with Euro V and Euro VI vehicles.

These findings imply that regulation is important for a bus service to follow the appropriate service quality criteria. Regulation should go hand in-hand with enforcement, even if the latter is performed indirectly. Evidence of this is the set fare structure that has to be paid by a smartcard, and requirements to comply by EU standards on emission.

\subsection{Network Planning and Operations}

Time-related issues were prevalent in Models 2 and 3. Maltese participants preferred Model 1 in this regard. Additionally, time-related issues transpired in secondary issues related to comfort in Models 2 and 3 . The bus service in both models suffered from severe delays, leading to crowding on-board the bus. Crowding led to thefts, uncomfortable ambient conditions, and restrictions to accessibility, which frustrated the participants. This situation also influenced negatively the bus drivers.

Bus drivers' attitudes improved in Model 2, when compared to Model 1. Nevertheless, new problems emerged in Model 3. Participants described the bus drivers as stressed, resulting from pressures to reach the destination on time, and overcrowding on the buses. These emotions led to repercussions on the drivers' driving behaviour, which consequently led to 
customer insecurity. These findings imply that it is necessary to address major issues such as 'time'; apart from its direct effects, it also has negative repercussions on other factors such as comfort and security.

\subsection{Fleet, Information, and Customer Satisfaction}

As discussed in section 6.1 the fleet improved, particularly in Model 4 regarding the impact on the environment. The other type of improvement following the reform was that the fleet became accessible with low floors (Models 2 to 4). This improvement was temporarily regressed in Models 2 and 3 because of the re-introduction of the sub-contracted vehicles that had high steps. This resulted from the need to improve time-related issues by increasing the fleet, and is another example of negative repercussions resulting from major problems (as discussed in section 6.2).

With regard to information, Table 1 showed that Models 2 to 4, improved in information dissemination. Interestingly, the interview participants revealed that they still relied more on on-site information, and on asking questions. Hence, implying that information has to be made available in all forms, and operators should not underestimate the basic need of customers' personal contact with staff.

The differing participant views show that expectations are important factors to consider in bus operations. Model 2 raised very high expectations to Maltese participants, and the initial problems resulted in low satisfactions, also leading to three participants changing from bus use to car use. This problem was felt in Models 3 and 4, because the participants' trust in the service was minimal. Evidently, the findings imply that operators and regulators should never underestimate expectations, on the contrary they should consider expectations, but with caution. When introducing a new project (as was the case of the reform in Malta's case) expectations should be kept low, to avoid setting individuals' standards too high, because if these standards are unreachable trust is lost.

\subsection{Identifying the best model of operation}

The four models of operation indicate that in all cases there were positive and negative issues that influenced the participants' attitudes towards the service. The main issue with Models 2 and 3 was punctuality and unreliability. This issue led the participants to say that in Model 1 the service was punctual and reliable. It was known, however, that during the operation of Model 1 there was no contract that bound the service by specific timetables (Attard, 2005 and MITC, 2008), and buses were not always punctual or available.

Following the reform, in Models 2 to 4, several service quality characteristics improved, including information, fleet, and impact on the environment. Nevertheless, each of these characteristics had its own problems. This study implies that so far what seems to be the best model of operation is one that binds the operator to a minimum level of service. Most importantly, however, this minimum level of service needs to be adhered otherwise it is useless. Hence, enforcement is an important component, which suggests that the regulator has a key role in bus service operations. Consequently, cooperation between the regulator and operator is a key component that builds trust. A bus service based on trust instils trust in the users and the potential users of the bus service. 


\subsection{Suggestions for bus service operations}

Based on the four models described in this paper, and the findings from the in-depth, semistructured interviews, we propose the following suggestions for improved bus service operations.

- Achieve excellence in punctuality, and reliability; these service quality characteristics are determinant factors of bus use

- Disseminate all information in all possible forms (electronic and hard copy), but do not underestimate that consumers prefer to interact with other people to gain information

- Consider bus drivers as important stakeholders, they contribute to the provision of the service, and contribute to the consumers' first impression of the bus company

- Use a bus fleet that suits the area where the bus service is operating

- Ensure cooperation between the regulating authority and the operator

- Avoid raising high expectations, and endeavour to gain trust with small success stories

- Ensure that the regulating authority and the bus operators follow the contract, and use it as a guideline for enforcement and operation.

\section{Acknowledgements}

This research is partially funded by the Malta Government Scholarship Scheme. The authors would like to thank all the interviewees who dedicated their time to contribute to this research.

\section{References}

Amaral, M. (2008). Public vs private management of public utilities - The case of urban public transport in Europe. Research in Transportation Economics, 22(1), 85-90. doi:10.1016/j.retrec.2008.05.021

Atlas.ti. (2013). Atlas.ti 6.2 Qualitative Data Analysis. Atlas.ti Scientific Software Development $\mathrm{GmbH}$.

Attard, M. (2005). Land transport policy in a small island State-the case of Malta. Transport Policy, 12(1), 23-33. doi:10.1016/j.tranpol.2004.09.001

Attard, M. (2012). Reforming the urban public transport bus system in Malta: Approach and acceptance. Transportation Research Part A: Policy and Practice, 46(7), 981-992. doi:10.1016/j.tra.2012.04.004

Attard, M. (2013). Effects on service quality following regulatory reforms in public transport in Malta. In Proceedings of the Transportation Research Board 92nd Annual Conference 12-17 January. Washington, D.C., USA.

Badami, M. G., \& Haider, M. (2007). An analysis of public bus transit performance in Indian cities. Transportation Research Part A: Policy and Practice, 41(10), 961-981. doi:10.1016/j.tra.2007.06.002

Bajada, T. (2015). The Malta Bus Service Reform: Implications for policy from a "natural experiment" of attitudes towards bus service quality, and modal shift. In M. Attard \& Y. Shiftan (Eds.), Sustainable Urban Transport (pp. 93-119). Emerald Publishing Limited. Retrieved from http://dx.doi.org/10.1108/S2044-994120150000007016

Balcombe, R., Mackett, R., Paulley, N., Preston, J., Shires, J., Titheridge, H., ... White, P. (2004). The demand for public transport : a practical guide. United Kingdom. Retrieved 
from http://eprints.ucl.ac.uk/1349/1/2004_42.pdf

Blundred, H. (1991). Buses: public service or private profit? Transportation Planning and Technology, 15(2-4), 107-114. doi:10.1080/03081069108717445

Braun, V., \& Clarke, V. (2006). Using thematic analysis in psychology. Qualitative Research in Psychology, 3(2), 77-101. doi:10.1191/1478088706qp063oa

Cambini, C., \& Filippini, M. (2003). Competitive Tendering and Optimal Size in the Regional Bus Transportation Industry. An Example from Italy. Annals of Public and Cooperative Economics, 74(1), 163-182.

Camilleri, I. (2013, February 10). EU action on bus fares. Times of Malta Online. Retrieved July 8, 2015, from http://www.timesofmalta.com/articles/view/20130210/local/eu-actionon-bus-fares. 456848

Childs, R., \& Sutton, D. (2008). Bus Regulation, Network Planning and Bus Service Procurement - The Malta Experience. In Association for European Transport and Contributors.

Cirillo, C., Eboli, L., \& Mazzulla, G. (2011). On the Asymmetric User Perception of Transit Service Quality. International Journal of Sustainable Transportation, 5(4), 216-232. doi:10.1080/15568318.2010.494231

Dalli, M. (2014, April 9). Arriva made $€ 23,226,998$ in sales from bus tickets. Malta Today. Retrieved April 9, 2014, from http://www.maltatoday.com.mt/news/national/37844/arriva_made_23226998_in_sales_f rom_bus_tickets\#.VNacwfnF9rs

De Oña, J., De Oña, R., Eboli, L., \& Mazzulla, G. (2013). Perceived service quality in bus transit service: A structural equation approach. Transport Policy, 29, 219-226. doi:10.1016/j.tranpol.2013.07.001

dell'Olio, L., Ibeas, A., \& Cecin, P. (2011). The quality of service desired by public transport users. Transport Policy, 18(1), 217-227. doi:10.1016/j.tranpol.2010.08.005

dell'Olio, L., Ibeas, A., \& Cecín, P. (2010a). Modelling user perception of bus transit quality. Transport Policy, 17, 388-397. doi:10.1016/j.tranpol.2010.04.006

dell'Olio, L., Ibeas, A., \& Cecín, P. (2010b). Modelling user perception of bus transit quality. Transport Policy, 17(6), 388-397. doi:10.1016/j.tranpol.2010.04.006

Eboli, L., \& Mazzulla, G. (2007). Service Quality Attributes Affecting Customer Satisfaction for Bus Transit. Journal of Public Transportation, 21-34.

Eboli, L., \& Mazzulla, G. (2012). Performance indicators for an objective measure of public transport service quality. European Transport, 51(3), 1-21.

European Commission. (2011). Future of transport. Analytical report. Hungary. Retrieved from http://ec.europa.eu/public_opinion/flash/fl_312_en.pdf

European Committee for Standardisation. (2002). Transportation - Logistics and services Public passenger transport - Service quality definition, targeting and measurement. Brussels, Belgium.

Finn, B. (2003). Advancing Urban Passenger Transport Reform in the Europe and Central Asia Region. Retrieved from http://Inweb18.worldbank.org/ECA/Transport.nsf/0/7ef77523de0d2eb885256f390040ec4 6/\$FILE/Reform Options Report - v3.1 - 31st December 2003.doc

Google Maps. (2015). Malta Public Transport Journey Planner. Website. Retrieved May 5, 2015, from http://www.publictransport.com.mt/searchresults

Gwilliam, K. (2008). A review of issues in transit economics. Research in Transportation Economics, 23(1), 4-22. doi:10.1016/j.retrec.2008.10.002 
Hastorf, A. H., Schneider, D. L., \& Polefka, J. (1970). Person perception. Reading, MA: Addison-Wesley.

Hefetz, A., \& Warner, M. E. (2012). Contracting or public delivery? the importance of service, market, and management characteristics. Journal of Public Administration Research and Theory, 22(2), 289-317. doi:10.1093/jopart/mur006

Hensher, D., \& Houghton, E. (2004). Performance-based quality contracts for the bus sector: delivering social and commercial value for money. Transportation Research Part B: Methodological, 38(2), 123-146. doi:10.1016/S0191-2615(03)00004-3

Hensher, D., Mulley, C., \& Yahya, N. (2010). Passenger experience with quality-enhanced bus service: The Tyne and Wear "superoute" services. Transportation, 37, 239-256. doi:10.1007/s11116-009-9240-x

Izatt, A. (2015, December). Establishing a Presence. Coach and Bus Week, 16-21.

Jarosz, A. (2011, September). Malta - Why it went wrong. Buses, 38-41.

Leech, B. L. (2003). Asking Questions: Techniques for Semistructured Interviews. Political Science \& Politics, 35(04), 665-668. doi:10.1017/S1049096502001129

Lidstone, J. G. (2011, September). Chaotic, but it worked. Buses, 42-43.

Lyons, A. G., Goodwin, P., Hanly, M., Dudley, G., Chatterjee, K., Anable, J., ... Susilo, Y. (2008). Public attitudes to transport: Knowledge review of existing evidence. Final report to the Department for Transport. Bristol, United Kingdom. Retrieved from http://eprints.uwe.ac.uk/10352/

Mahmoud, M., Kashyap, A., \& Hine, J. (2014). Stakeholders' perspectives towards bus quality indicators. Proceedings of the Institution of Civil Engineers. Transport. Retrieved July 9, 2015, from http://cat.inist.fr/?aModele=afficheN\&cpsidt=28500222

Malta Environment and Planning Authority. (2003). Transport Topic Paper. Floriana, Malta. Retrieved from http://www.mepa.org.mt/lpg-structureplanreview

Malta Public Transport. (2015). Malta Public Transport. Website. Retrieved May 5, 2015, from https://www.tallinja.com/

Mathisen, T. A., \& Solvoll, G. (2008). Competitive tendering and structural changes: An example from the bus industry. Transport Policy, 15, 1-11. doi:10.1016/j.tranpol.2007.08.002

Meek, S., Ison, S., \& Enoch, M. (2009). Stakeholder perspectives on the current and future roles of UK bus-based Park and Ride. Journal of Transport Geography, 17(6), 468-475. doi:10.1016/j.jtrangeo.2008.10.007

Micallef, K. (2014, September 30). Talks with Spanish bidder at advanced stage - Mizzi. Times of Malta Online. Retrieved September 30, 2014, from http://www.timesofmalta.com/articles/view/20140930/local/Talks-with-Spanish-bidder-atadvanced-stage-Mizzi.537815

Miles, M., \& Huberman, A. (1994). An Expanded Sourcebook. Qualitative Data Analysis. (2nd Editio.). London, UK: Sage Publications.

Ministry for Tourism. (1999). Carrying Capacity Assessment for Tourism in the Maltese Islands: Survey Draft. Valletta.

Ministry of Infrastructure Transport and Communications. (2008). PUBLIC TRANSPORT IN MALTA. A vision for Public Transport which fulfils public interest in the context of environmental sustainability. Online report. Valletta, Malta. Retrieved July 8, 2015, from http://www.transport.gov.mt/admin/uploads/media-library/files/Vision - Public Transport in Malta - Buses - July 2008.pdf

Mitric, S., \& Chatterton, I. (2005). Towards a discussion of support to Urban Transport development in India. 
Mizzi, D. (2014, November 27). €23 million subsidy for bus service set to increase. Malta Today. Retrieved November 27, 2014, from

http://www.maltatoday.com.mt/news/court_and_police/46841/23_million_subsidy_for_b us_service_set_to_increase\#.VNaiXvnF9rs

Muñoz, J. C., \& Gschwender, A. (2008). Transantiago: A tale of two cities. Research in Transportation Economics, 22(1), 45-53. doi:10.1016/j.retrec.2008.05.010

Nash, C., \& Bray, D. (2014). Workshop 5 Report: The roles and responsibilities of government and operators. Research in Transportation Economics, 48, 286-289. doi:10.1016/j.retrec.2014.09.054

National Statistics Office. (2014). Malta in Figures 2014. Online report. Valletta, Malta. Retrieved July 9, 2015, from https://nso.gov.mt/en/publicatons/.../Malta_in_Figures_2014.pdf

Oliver, R. (1980). A Cognitive Model of the Antecedents and Consequences of Satisfaction Decisions. Journal of Marketing Research, 17(4), 460-469.

Paulley, N., Balcombe, R., Mackett, R., Titheridge, H., Preston, J., Wardman, M., ... White, P. (2006). The demand for public transport: The effects of fares, quality of service, income and car ownership. Transport Policy, 13(4), 295-306. doi:10.1016/j.tranpol.2005.12.004

Preston, J. (2014). Editorial: Thredbo 13 workshops. Research in Transportation Economics, 48(January 2013), 3-8. doi:10.1016/j.retrec.2014.09.025

Robledo, M. A. (2001). Measuring and managing service quality: integrating customer expectations. Managing Service Quality, 11(1), 22-31.

Roschlau, M. W. (2008). Public transport policy in Canada and the United States: Developing political commitment from the federal government. Research in Transportation Economics, 22, 91-97. doi:10.1016/j.retrec.2008.05.024

Sakai, H., \& Takahashi, Y. (2013). Ten years after bus deregulation in Japan: An analysis of institutional changes and cost efficiency. Research in Transportation Economics, 39, 215-225.

Sansone, K. (2014). Public transport subsidy not as big as Germany's on per capita basis Transport Minister. "Bus drivers will not lose their job". Times of Malta Online. Retrieved from http://www.timesofmalta.com/articles/view/20141121/local/public-transportsubsidy-not-as-big-as-germanys-on-per-capita-basis-transport-minister.545074

Scheiner, J., \& Holz-Rau, C. (2007). Travel mode choice: affected by objective or subjective determinants? Transportation, 34(4), 487-511. doi:10.1007/s11116-007-9112-1

Stradling, S., Carreno, M., Rye, T., \& Noble, A. (2007). Passenger perceptions and the ideal urban bus journey experience. Transport Policy, 14(4), 283-292. doi:10.1016/j.tranpol.2007.02.003

Sutton, D. (2000). Scheduled Bus Service in Malta - A Viable Alternative to the Car? Paper presented at the Public Transport Authority National Conference. 13th March (pp. 114). Moving 2000, Malta.

Tang, S., \& Lo, H. K. (2008). The impact of public transport policy on the viability and sustainability of mass railway transit - The Hong Kong experience. Transportation Research Part A: Policy and Practice, 42(4), 563-576. doi:10.1016/j.tra.2008.01.022

Teas, K. R. (1993). Expectations, Performance Evaluation, and Consumers' Perceptions of Quality. The Journal of Marketing, 57(4), 18-34.

Tertoolen, G., van Kreveld, D., \& Verstraten, B. (1998). Psychological resistance against attempts to reduce private car use. Transportation Research Part A: Policy and Practice, 32(3), 171-181. doi:10.1016/S0965-8564(97)00006-2 
Times of Malta Online. (2010, July 21). Arriva chosen as preferred bidder for new bus service. Online Newspaper, pp. 1-11. Retrieved from http://www.timesofmalta.com/articles/view/20100731/local/arriva-chosen-as-preferredbidder-for-new-bus-service.320367

Times of Malta Online. (2014). Updated -Transport Malta sells the bendy buses for $€ 601,200$ , for use in Sudan. Online Newspaper. Retrieved May 26, 2015, from http://www.timesofmalta.com/articles/view/20140218/local/bendy-buses-to-be-shippedto-sudan.507334

Transport Malta. (2010). National Household Travel Survey 26th May 2010. Retrieved from http://www.transport.gov.mt/admin/uploads/media-library/files/NHTS2010 Report.pdf_20120502091559.pdf

Transport Malta. (2014). Expression of interest notice for the provision of scheduled bus services in Malta and Gozo. Marsa.

Vassallo, R. (2011, November 19). Brussels bombarded by complaints about Arriva Malta's "discriminatory" fares. Malta Today. Malta. Retrieved July 8, 2015, from http://www.maltatoday.com.mt/news/national/13944/brussels-bombarded-bycomplaints-about-arriva-malta-s-discriminatory-fares\#.VbleSPIViko

Walters, J., \& Jansson, J. O. (2008). Risk and reward in public transportation contracting. Research in Transportation Economics, 22(1), 26-30. doi:10.1016/j.retrec.2008.05.007

Wang, S.-M., Feng, C.-M., \& Hsieh, C.-H. (2010). Stakeholder perspective on urban transport system service quality. Total Quality Management \& Business Excellence, 21(11), 1103-1119. doi:10.1080/14783363.2010.529329

White, P. (1999). Public Transport: Its Planning Management and Operation (5th Ed.). Routledge, Taylor \& Francis Group, London.

Xuereb, M. (2001). Public Transport in Malta: An Analysis of Demand for the Scheduled Bus Serivce. Bank of Valletta Review, (23), 1-27. 